\title{
Ivan Dorovský a rusistika
}

\author{
Ivo Pospíšil \\ (Brno, Česká republika)
}

Dne 24. srpna 2021 opustil tento svět emeritní profesor Masarykovy univerzity, akademik Makedonské akademie věd a umění, prof. h. c. Univerzity svatých Cyrila a Metoděje ve Skopje, emeritní člen Ústavu slavistiky Filozofické fakulty Masarykovy univerzity, emeritní proděkan Filozofické fakulty Masarykovy univerzity, předseda a člen vědeckých komisí a grémií, zakladatel a předseda Společnosti prátel jižních Slovanů, nositel Ceny Františka Alexandra Zacha a řady dalších vědeckých ocenění. Převážná část životní dráhy prof. PhDr. Ivana Dorovského, DrSc., je spojena s bývalým Československem a s nynějši Českou republikou, konkrétně s Moravou a s Brnem. Přichází sem jak třináctiletý v důsledku občanské války v Řecku, kde se 18. května 1935 (historii „záhady“ kolem skutečného data jeho narození pomineme) ve vesnici Čuka narodil. V Československu ukončil základní, středoškolské a vysokoškolské vzdělání: na Filozofické fakultě brněnské univerzity vystudoval ruštinu a bulharštinu. V letech 1961-1968 pracoval na katedře jazyků na Lékařské fakultě brněnské univerzity, později na katedře historie a etnografie střední, jihovýchodní a východní Evropy, na katedře slavistiky a posléze v Ústavu slavistiky Masarykovy univerzity. Nutno zdůraznit všestrannost Ivana Dorovského: od publicistiky, recenzí a drobných článků na počátku jeho tvưrčí dráhy (a toto pole nikdy neopouštěl) $\mathrm{k}$ rozsáhlejším přehledům, vědeckým studiím, překladům, monografím a vlastní básnické a prozaické tvorbě. Znal takřka všechny slovanské jazyky slovem a písmem. Jako vědec se Ivan Dorovský profiloval jako komparatista širokého kulturologického záběru s primární orientací na Balkán a Mediterán, jak se ostatně jmenuje jedna z jeho četných knižních monografických studií. Významná je jeho práce lexikografická, bibliografická a publikačně organizační: mnozí si také jistě připomenou fakt, že z časopisu Universitas udělal v letech 1971-1990 významné brněnské populárněvědecké periodikum s literárními ambicemi v situace tehdejší neexistence podobného časopisu $\mathrm{v}$ městě Brně. Neméně pozoruhodná je jeho organizační a ediční práce ve Společnosti přátel jižních Slovanů; byl také vedoucím redaktorem jejího časopisu. Ivan Dorovský byl spiritus agens nesčetných publikačních aktivit, zejména z okruhu jihoslovanských literatur a Balkánu, editorem 
a překladatelem, školitelem. Založil tradici brněnských balkanistických sympozií, vytvářel bibliografii české balkanistiky a profiloval pravidelné česko-makedonské konference a editoval jejich publikační výstupy. Tvůrčí aktivity Ivana Dorovského pokrývaly rozsáhlé teritorium od vlastní umělecké - básnické i prozaické - produkce k překladatelství, lingvistice, literární vědě, slavistice, balkanistice, translatologii, komparatistice a dál až $\mathrm{k}$ folkloristice, etnologii, kulturologii a historii, nemluvě o dalších oborových přesazích, když pomineme jeho zajímavý cestopis o Austrálii [DOROVSKÝ 1985], překlad klasické, pro Makedonce zakládací práce Krste Misirkova $O$ makedonských záležitostech, [MISIRKOV 2012] a pamětí $S$ domovem $v$ srdci [DOROVSKÝ 2014].

Původní studijní obory zesnulého - ruština a bulharština - se promítly i do jeho pedagogického a vědeckého působení. Představoval na Filozofické fakultě Univerzity Evangelisty Purkyně a později opět Masarykovy dlouhou dobu bulharistiku (spolu s jinými), založil makedonistiku a později se zasloužil o serbistiku a slovenistiku. Pokud jde o Bulharsko a Makedonii (používám starého, uzuálního termínu, i když se Makedonie po rozbití Jugoslávie jmenovala a zase jmenuje jinak) a zdůrazňoval nejen přirozenou blízkost (jiní hovoří o totožnosti), ale i odlišnost obou jazyků a národů, což mu přinášelo řadu problémů, které musel on sám, ale hlavně jeho čeští nadřízení a kolegové na vysoké úrovni řešit a vysvětlovat.

Jako slavista a balkanista širokého záběru využíval často ruštiny jako slovanského esperanta. Tu nejen vystudoval, ale jako jižní Slovan k ní měl blízko, když si uvědomíme, že vlastně celá ruská gramatika je - odhlédneme-li od fónické stránky staroslověnská, nemluvě o silném impaktu lexikálně stylistickém. Rusky napsal knižní práci o Rajku Žinzifovovi [DOROVSKÝ 1988] a některé články.

Během studií rusistiky vytvořil seminární práci, ke které se $\mathrm{k}$ stáru vrátil. V roce 2010, kdy slavil pětasedmdesátiny, mě požádal, abych mu vydal toto pojednání o Puškinově rané básni Volnost/Svoboda (Вольность, 1817); jde tu ve stopách Radiščevovy stejnojmenné básně, spolu s Rozmluvou o Lomonosovovi, Слово о Ломоносове, včleněné do kryptocestopisu Путешествие из Петербурга в Москву - Puškin jej později parafrázoval jako Путешествие из Москвы в Петербург z let 1833-1835 [MEJLACH 1949; POSPÍŠIL 2006]. Přijal jsem to jako běžnou kolegiální záležitost, ale při čtení této juvenilie, která vyšla s podporou dvou profesních spolků, jsem pochopil, že se v ní jako v kapce vody zrcadlí celé badatelské východisko Ivana Dorovského. Tím jsem se jako editor zabýval v českém úvodu rusky psané publikace. Vzhledem k tomu, že jsem nekrolog Ivana Dorovského uveřejnil už v Proudech [POSPÍŠIL 2021] a kolegové o zvěčnělém badateli píšou do různých českých i zahraničních periodik, rozhodl jsem se uctít jeho památku právě přetištěním této krátké studie, zasuté v malotirážním výstupu [POSPÍŠIL 2010]. Přiznám se, že při novém čtení práce mladého Ivana Dorovského [DOROVSKÝ 2010], původně z roku 1957, a své studie z roku 2010 jsem si uvědomil, 
jak je tato tematika dnes, na pozadí nejnovějších událostí, až úděsně aktuální, současná i možná anticipující hrozivou budoucnost.

(Publikuje se bez podstatných změn, jen s drobnými opravami, upřesněními a doplňky.)

\section{Básník, jeho vykladač a souvislosti (Juvenilie Ivana Dorovského jako zárodek badatelské dráhy)}

Každý badatel nějak začíná a životní i badatelská dráha každého z nich se odvíjí zvláštním způsobem. Juvenilie, seminární práce o Puškinově ódě Volnost, jejíž sepsání datuje Ivan Dorovský 1. květnem 1957, je v tomto smyslu příznačná. Vydáváme ji $\mathrm{z}$ autorova podnětu $\mathrm{k}$ jeho pětasedmdesátinám $\mathrm{v}$ původní podobě jen s elementární jazykovou korekturou (byly opraveny jazykové chyby a překlepy, jinak však byla textace zcela zachována), s tímto úvodem a přiloženým textem analyzované ódy. Práce je mi osobně blízká, nebot jako každý rusista jsem se i já s Puškinem musel nějak střetnout. Nebylo to často, ale byla to setkání pro mě významná: jedním z nich byla knížka napsaná na počest 200. výročí básníkova narození a vydaná tedy v roce $1999 \mathrm{Na}$ výspě Evropy, za kterou jsem posléze obdržel od Společnosti Leopolda Vrly cenu [POSPÍŠIL 1999]. Druhé bylo spojeno s prací na knize esejů a literárněteoretických a literárněkritických pojednání s pasternakovským názvem $A \check{z}$ se vyčasí [POSPÍŠIL 2002] a na nové knížce o ruském románu, která vyšla roku 2005 pod názvem Ruský román znovu navštívený [POSPÍŠIL 2005]. Zatímco v první jsem se snažil pokrýt Puškinovu činnost ve větší šíři, například i jeho tvorbu publicistickou a historiografickou, ale i historicky orientovaná díla básnická a ovšem Evžena Oněgina, v druhé jsem se více zaměřil nejen na „román ve verších“, ale také na jeho tvorbu románových fragmentů - to nám ukázalo Puškina ve zcela jiném světle i jeho posedlost romanopisectvím vynuceným změněnými společenskými poměry [POSPÍŠIL 2006]. I to v jistém smyslu svědčí o jeho společenských a politických názorech, které poprvé s neobyčejnou, byt’ rozpornou silou vyložil v ódě Svoboda (Volnost), stejně jako v tématu šílenství jako ztráty rozumu a průniku do jiného, nám dosud nedostupného světa, což jsem už popsal dříve a jinde [POSPÍŠIL 1995]. Z tohoto myšlenkového okruhu vychází i přítomná úvaha.

Na počátku Puškinova konfliktu s mocí stojí vzývání osvícenských ideálů svobody a demokracie, které byly poznamenány americkými a francouzskými zkušenostmi a volně se spojovaly s vědomím národní velikosti po vítězných válkách s Napoleonem: sama postava Napoleona, původně adorovaný romantický symbol, se mění v emblém panovačnosti a neúcty $\mathrm{k}$ člověku: „Všichni se zhlížíme v Napoleonech a milióny dvounohých bytostí jsou pro nás pouhou podnožíi. Tato parafráze jedné digrese z Evžena Oněgina se stala nakonec východiskem úvah Dostojevského, jak je 
nacházíme ve Zločinu a trestu a dalších románových dílech tohoto autora, stejně jako v axiologickém modelu Tolstého Vojny a míru. Skutečný konflikt s mocí následoval až po sérii kousavých aforismů na ministra Arakčejeva, ale také na samotného Alexandra I.

Vrat̉me se však k Puškinovým východiskům z konce 10. let 19. století. V roce 1817 píše Puškin ódu Volnost, v níž ožívá osvícenská teze o zákonech, které vládnou i nad vládci.

Osvobození člověka je spojeno se vzděláním („dav nevzdělaný“), a svoboda zpětně vzdělání, rozvoj člověka, jehož „práci, majetek a čas“ si přisvojilo „panstvo divoké“, vytváří. Sám akt osvobození na carův pokyn čili podle carovy vůle je výsledkem osvícení, které prrinese krásu. Tuto symbiózu dodržování Zákona, jehož výsledkem je krása a klid, nacházíme ostatně i v básních Puškinova staršího př́tele Vasilije Andrejeviče Žukovského (1783-1852). Jako čtrnáctiletý (1797) píše ódu, v níž se jakoby symbolicky spojují jeho „fixní ideje“, klíčové myšlenkové okruhy: oslava klidu, harmonie a ruského samoděržaví. Příznačné jsou již první dva verše: „Odkud je zlaté ticho / v blažené severní zemi?“ „Zlatý klid“, který podle dětského básníka vládne v severní mocnosti, je podepřen pojmy jako „zákon“, „smíření“ a „moudrost“ - nepíše se zde ovšem nic o nevolnictví, spíše se má na mysli, že tato země „zlatého ticha“ byzantských ikon je záštitou proti chaosu, který zachvátil Evropu po Francouzské revoluci. I Puškin ostatně chápe tuto revoluci jako zločinnou a viní z ní nikoli „nevzdělaný dav“, ale mocné panstvo, které nedodržovalo zákon, jenž vládne i nad ním: Lid sledující Ludvíkovu popravu je užaslý, nebot v panovníkově předchozím zpupném vládnutí i v jeho popravě vidí narušení řádu: ze řetězu byly puštěny nekontrolovatelné síly chaosu a neklidu.

Snaha zachytit dominantní a současně protikladné síly epochy se projevila stejnou silou i pod dobovým tlakem $\mathrm{v}$ žánrové podobě románu. $\mathrm{V}$ podstatě všichni velcí Rusové směřovali z literatury ven do širokých prostor kontemplativnosti, publicistiky, filozofičnosti, historie: stačí se podívat na samotného Puškina, ale i na Gogola, který na Petrohradské univerzitě přednášel kurs světových dějin, nebo na A. I. Solženicyna, jenž svazující limity krásné literatury překračoval nejvíce v Souostroví GULAG. Puškin sám je podle Vadima Kožinova završením tzv. ruské renesance: podobá se v jisté omezené míre renesančním titánům, nebot obepjal jak lyriku, tak narativní poezii (poémy) a velkou i drobnou dramatickou formu, stal se novinářem, literárním kritikem a historikem, ale i historikem obecným svou skvělou materiálovou a varující prací o Pugačovově povstání. Historie bylo Puškinovo dominantní téma: Volnost to dokládá na samém počátku jeho tvůrčí dráhy, historické poémy, historická próza a historiografie na jejím konci.

S Puškinovým tzv. historismem je spjato i jeho mnohočetné směřování k románu, jehož se mu podařilo dosíci jen zřídka, je dobově významné. Fascinace př́během, 
hledání syžetu, dynamičnost líčení, ale také smysl pro plynutí dějin, ukotvenost v lokalitě, napětí lokality a totality, ale především soustředění románových fragmentů na stěžejní utkvělé představy, topoi, na která jsem průběžně upozorňoval, ukazují na motivickou a myšlenkovou bohatost, na příznačné opakování svědčící o Puškinovi jako prozaikovi, který se snaží své dílo ukotvit na několika nosnících či opěrných plochách, jak to s oblibou činí novelisté: Puškin byl primárně romanopiscem západního stylu v dynamičnosti a dějovosti, současně však šel za tyto modely, pohrával si s nimi, palimpsesticky jich využíval, travestoval, parodoval je a nořil je do „tekouci“ reality, nekonečně plynoucího času a nedozírného ruského prostoru (pocity marnosti, deziluze, nudy, eskapismus a exotismus, odchod za hranice, hledání cizích prostředí). Je tedy velkým románovým hledačem, který spíše inicioval, než ukončoval - v tom je jeho osud velmi ruský. Právě v próze a zejména $\mathrm{v}$ románu a pnutí $\mathrm{k}$ němu vyvrací svou pověst jednoznačného syntetika, jenž dovršil epochu a vytvořil literární (spisovnou) ruštinu; jeho hledání románového tvaru ukazuje, že hledal jeho jazyk, jeho př́iběhové zřetězení a zkoušel různé jeho typy, které se staly modelovým východiskem ve zlatém věku ruské literatury a hlavně ruského románu.

Puškinovým erbovním tématem je pád rodové šlechty, fascinuje jej Napoleonovo ruské tažení - nepřímo je doložitelné, že o něm chtěl napsat román. $\mathrm{V}$ různých románových fragmentech se znovu a znovu objevuje takřka již paranoidní pasáž o rodové šlechtě. Vadí mu chudnutí rodové šlechty, její ponižování a neúcta $\mathrm{k}$ tradici a minulosti: úřednická aristokracie nemůže nahradit aristokracii rodovou (to je přesně to, co zastánce třetího stavu Faddděj Bulgarin na šlechtě nenáviděl, totiž, že její osudy jsou od kolébky predeterminovány). Zde je také př́íčina zásadních rozporů Puškina a Bulgarina: zatímco Puškin v tom rozhodně není demokratický, dá na zvykové právo, plnění nepsaných dohod a na osvícenost panstva, Bulgarin je - jak už řečeno - šampiónem rodící se ruské buržoazie; jeho román se podobá zmravněle didaktickému pikaresknímu románu, Puškinova díla se odehrávají stále v prostředí šlechtických salonů a jsou neseny nostalgií ponížené rodové šlechty; pro Bulgarina je tato šlechta nebezpečím pro stabilitu samoděržaví, pro Puškina právě ona utváří Rusko a jeho autokratickou moc. Zatímco Bulgarinův román stojí na bloudění vyvržence, který nakonec nachází opěrný bod a usazuje se v měštanském, řekli bychom takřka biedermeierovském „domácím štěstí “ [POSPÍŠIL 1988; POSPÍŠIL 1993a; POSPÍŠIL 1993b; POSPÍŠIL 1998; POSPÍŠIL 2016; POSPÍŠIL 2018], Puškin vychází z inteligentní a ironické hry s klasickými románovými schématy: pohyb, sjízdění hostů, salon, divadlo, ples, místa, kde se lidé setkávají a kde se zauzlují jejich prŕběhy; nebo někdo někam přijede, je válka nebo se alespoň vbrzku očekává, je tu mladý muž a mladá dívka, eventuálně jejich korespondenční styk, kde se protínají dvě původně zrcadlově jdoucí linie - to jsou oblíbené Puškinovy postupy. Nutno jen dodat, že oba našly v ruském románu pokračovatele, i když, jak se zdá, Puškinova linie byla bohatší 
a známější (Tolstoj, Dostojevskij - proti stojí Leskov se svým bulgarinovským skazem a bloudícími vypravěči nebo v lokalitě tesknícími donkichoty).

Vycházím z teze, že v postupu mladého badatele, autora seminární práce o Puškinově ódě Svoboda, se znovu vyjevuje půdorys celé jeho badatelské dráhy a jeho vědeckého profilu. Začíná příznačně žánrem, který je v konfrontaci s novodobou literaturou výjimečný a sleduje její tradici až do míst, jež jsou jeho srdci blízká, tedy do řecké a ř́mské antiky. Klasicky líčí vývoj a typické modely západoevropské ódy a potom popisuje genezi ruské ódy období klasicismu až k Puškinovi. Druhou velkou část práce tvoří deskripce a výklad textu básně.

Příznačný je autorův „historismus“ nebo, jak se dnes ř́íká, „historicita“, tj. důraz na genezi žánru a textu: zaujímá ho např́klad, kdy óda vznikla, a sleduje spory kolem její datace. Ve výkladu textu převažuje společensko-kritický aspekt, tj. v podstatě sledování Puškinových politických názorů. Dorovský tu rozhodně není schematický: jednak polemizuje s falešným pojetím revolučnosti Puškinovy básně, i když zároveň obnažuje - ale jinak - její revoluční jádro. Právě to se stalo, jak víme, obsahem debat o Puškinově děkabrismu. Je sice pravda, že při domovních prohlídkách osnovatelů spiknutí a koordinátorů vystoupení na Senátním náměstí (ozbrojené jednotky Jižního spolku na území dnešní Ukrajiny, tj. v jižní části Ruské říše byly potlačeny až v lednu únoru 1826) se nacházely Puškinovy básně, básně asi nechtěného barda spiknutí, ale Puškinovy názory byly asi složitější a nejednoznačnější, stejně jako jeho vztah k carovi jako otci: na to ostatně Dorovský naráží, byt’ opatrně. Je ovšem otázka, nakolik se mladý Puškin ve věku 18 let podobá zkušenějšímu básníkovi, jenž prošel ohněm politické perzekuce a byl uvězněn ve zlaté kleci carského dvora coby kamer-junker s privilegiem carovy cenzury: to ho ještě více vydělilo $\mathrm{z}$ běžného literárního života tehdejšího Ruska: byl, řekli bychom, carovým milovaným neprrítelem, zatímco Fadděj Venědiktovič Bulgarin spiše carovým nemilovaným až nenáviděným spojencem. Je zřejmé, že Puškinovy názory se posouvaly, že mladistvé iluze o revoluci a svobodě, stejně jako změně společenského uspořádání Ruska doznaly změn - právě oproti ztlumenému radikalismu ódy Volnost. Typickým př́kladem je nejen Historie Pugačovovy vzpoury (История пугачевского бунта), hodnoticí název, jenž mu vnutil car na rozdíl od původního Historie Pugačova, pod nímž vychází dnes, ale především historické poémy nahližející historii zezdola, z pozice „malého ruského člověka“, jehož dějiny tvořené ruskými Napoleony drtí, a také proslulá recenze Pamětí fohna Tannera.

Roku 1836 vychází v časopise Sovremennik rozsáhlá recenze A. S. Puškina nazvaná Джон Теннер (John Tanner). Představuje kritický komentář knihy, kterou vydal roku $1830 \mathrm{v}$ New Yorku Edwin James, znalec života severoamerických Indiánů. Jde o Jamesův záznam a adaptaci originálního vyprávění Johna Tannera, muže, který prakticky celý život prožil mezi algonkinskými Indiány (původně žijícími na území od Atlantského oceánu k Velkým jezerům). Jako dítě jižanského osadníka byl Indiány 
unesen, držen dlouhá léta jako zajatec, pak naturalizován a zcela integrován do indiánského společenství. E. James ličí Johna Tannera jako padesátiletého muže, mohutné tělesné stavby, rychlých reakcí a nekompromisnosti, jíž uchvacoval i Indiány [TANNER 1830; TANNER 1940; TANNER 1953; TANNER 1956].

Ve 20. a 3o. letech předminulého století začaly být vzpomínky bělochů, kteří prožili podstatnou část života mezi Indiány, populární. Tannerovo vyprávění se však od nich liší tím, že autor energicky a jasnozrrivě uviděl za svým osobním dobrodružstvím strukturu života odlišného národního společenství a mimovolně tak položil pro Spojené státy zásadní indiánskou otázku: možnost integrace původních obyvatel do systému buržoazní demokracie. Toho využil editor Edwin James, který dílo opatřil rozsáhlou předmluvou, komentářem a př́lohou, kde mimo jiné vyložil svou koncepci indiánské otázky. Domnívá se, že Indiáni jsou civilizací značně poškozeni, nebot ta nemá pouze světla, ale také výrazné stíny. Jako podstatné uvádí kořistnický obchod kožišinami, který devastuje rozsáhlá území, alkoholismus a nakažlivé nemoci, které Indiány hubí po tisících, a celkový mravní úpadek, který z toho vyplývá. Také plány na vystěhování Indiánů do neplodných pustin považuje za neobyčejně škodlivé: „The project of congregating the Indians from the extended portions of the United States, in some place not only west of the Mississippi, but westward of the arable lands of Missouri and Arkansas, in those burning deserts which skirt the eastern base of the Rocky Mountains, is, perhaps, more pregnant with injustice and cruelty to the people, than any other." [TANNER 1830, 19, 21] Další plán „nechat Indiány být“ (,let the Indians alone“) naráží na řadu nepřekonatelných překážek (zastavit kolonizaci kontinentu je z hlediska ekonomického rozvoje a př́livu přistěhovalců nemožné). James proto navrhuje, zcela v duchu dobových představ, integraci Indiánů do anglofonního společenství, a to integraci ekonomickou, politickou i kulturní: „As separate and independent tribes retaining their own language, manners and opinions, it is probable they cannot long continue in existence." [TANNER 1830, 280-281] John Tanner se s Indiány sžil, oženil se zde a měl děti, posléze se přiblí̌zil bělochům, naučil se znovu anglicky, stal se tlumočníkem a odešel s rodinou do New Yorku. Tři z jeho dětí však s Indiány zůstaly.

Zájem o USA v tehdejší Evropě byl podnícen řadou publikací. Téměř na počátku stojí kniha Abbé Raynala (1713-1796) Histoire philosophique et politique des établissements et du commerce dans les deux Indes [RAYNAL 1770], v níž je kriticky posuzováno úsilí kolonizátorů v Americe a obchod s černými otroky. Vítězná válka za nezávislost znovu probudila evropský zájem, v němž se realizovalo i Rusko (Kateřina II. si psala s Washingtonem o indiánských nářečích a Alexandr I. vedl korespondenci s Jeffersonem). Samostatnou kapitolou v rusko-amerických kulturních vztazích je cestopis Pavla Sviňjina (Павел Свиньин, 1787-1839), spolužáka básníka Vasilije Andrejeviče Žukovského ze Šlechtického penziónu (Благородный пансион), který v letech 1811-1813 pracoval jako tajemník generálního konzulátu ve Philadelphii. Jde 
о knihu Опыт живописного путешествия по Северной Америке [SVIN'IN 1815]. Jsou v ní obsaženy, kromě deklamátorského patosu, první kritické tóny, týkající se indiánské otázky i stinných stránek demokracie. Značný význam měla i Svininova anglicky psaná kniha vydaná v Americe Sketches of Moscow and St. Petersburg [SVIN'IN 1813; SVIN'IN 1814]. Celý kontext kritického obrazu Ameriky dotvář́ v Rusku studie Alexise de Tocquevilla (1805-1859) De la démocratie en Amérique (Bruxelles 1835, druhý díl vyšel až 1840, amer. vyd. New York 1841, čes. jako Demokracie v Americe, [TOCQUEVILLE 1992; TOCQUEVILLE 2000; TOCQUEVILLE 2012; TOCQUEVILLE 2018]). Tento kritický tón zachytil ve sledované recenzi i A. S. Puškin [PUŠKIN 1958]. V americké demokracii hledali vzor mnozí politikové tehdejšího světa, mezi jinými i někteří děkabristé, Puškinovi přátelé. Současně se však stále více, kromě pokrokových stránek systému, odkrývala i jeho negativní podoba, která nabádala k hluboké analýze: „С некоторого времени Северо-Американские Штаты обращают на себя в Европе внимание людей наиболее мыслящих. Не политические происшествия тому виною: Америка спокойно совершает свое поприще, доныне безопасная и цветущая, сильная миром, упроченным ей географическим ее положением, гордая своими учреждениями. Но несколько глубоких умов в недавнее время занялись исследованием нравов и постановлений американских, и их наблюдения возбудили снова вопросы, которые полагали давно уже решенными. Уважение к сему новому народу и к его уложению, плоду новейшего просвещения, сильно поколебалось. С изумлением увидели демократию в ее отвратительном цинизме, в ее жестоких предрассудках, в ее нестерпимом тиранстве. Все благородное, бескорыстное, все возвышающее душу человеческую - подавленное неумолимым эгоизмом и страстью к довольству (comfort): большинство нагло притеняющее общество; рабство негров посреди образованности и свободы; родословные гонения в народе, не имеющем дворянства; со стороны избирателей алчность і зависть; со стороны управляющих робость и подобострастие; талант, из уважения к равенству, принужденный к добровольному осракизму; богач, надевающий оборванный кафтан, дабы на улице не оскорбить надменной нищеты, им втайне презираемой: такова картина Американских Шатотов, недавно выстевленная перед нами." [PUŠKIN 1958, 434-435]

Je pravděpodobné, že Puškin originál knihy nikdy neviděl: čerpal z francouzského překladu Mémoires de fohn Tanner, ou trente années dans les déserts de l'Amérique $d u$ Nord (2 sv., [TANNER 1835]) a zejména z předmluvy vydavatele a překladatele Ernesta de Blossevilla. Vcelku je Puškinova recenze nejen kritikou stinných stránek americké demokracie obecně, ale také amerického pragmatismu před pragmatismem, který se projevil i v Jamesově předmluvě, v níž se de facto navrhuje násilná integrace Indiánů. Poměrně rozsáhlé partie recenze jsou vlastně komentáře a př́mé citáty z Tannerových vzpomínek, které Puškin používá jako ilustračního materiálu. $\mathrm{Na}$ 
př́kladu výměny Johna Tannera za soudek whisky a několik liber tabáku ukazuje Puškin na úpadek osobnosti a nivelizaci mravních hodnot. $Z$ textu vyzvedává zejména škodlivost civilizace pro Indiány, ale nevyhýbá se ani ilustraci stinných stránek charakteru domorodců. Spojené státy a jejich systém buržoazní demokracie se už zdaleka nejeví vzorem pro podobné uspořádání $\mathrm{v}$ tehdejším autokratickém Rusku [TOCQUEVILLE 2000; POSPÍŠIL 1986; TOJBIN 1980; JERJOMIN 1963; ROTHE 1968; BODEN 1968].

Juvenilie Ivana Dorovského vytváří zajímavé badatelské podloží, které se potom $\mathrm{v}$ jeho vědecké dráze pozoruhodně naplňuje: úcta $\mathrm{k}$ žánrovým formám a $\mathrm{k}$ textu samotnému, zkoumání toho, jak se do textu promítají ideje a společenské poměry, úzký vztah k historii a její zpětné promýšlení v kulturním utváření literárního artefaktu. To provázelo Ivana Dorovského na celé dráze lemované komparatistickými literárními i široce kulturními a historickými tématy, to ho přivedlo do týmu proslulého Dionýze Durišina (1929-1997), jeho př́tele, jenž se nespokojil s imanentním zkoumáním literatury a šel tam, kde dnes srovnávací studium je: ke kultuře a společenským celkům, $\mathrm{k}$ typu bádání, jenž dnes $\mathrm{v}$ západní Evropě nezř́́dka napodobují, aniž by odkázali k pramenům. Současně se zde zrcadlí Dorovského slavistický záběr i jeho evropská dimenze, jak ukazují jeho nejnovější práce Slovanské meziliterární shody a rozdíly (2004) Slovanské literatury a dnešek (2008). Jen málokomu se podaří utvářet tak kontinuálně a přitom inovativně zvrásněnou tvůrčí dráhu.

\section{Bibliografie:}

BODEN,D. (1968): Das Amerikabild im russischen Schrifttum bis zum Ende des 19. Jahrhunderts. Hamburg.

DOROVSKÝ, I. (1985): Odjiždím do Austrálie, neoplakávejte mne. Brno.

DOROVSKÝ, I. (1988): Rajko Žinzifov. Vozdejstvije russkoj i ukrainskoj literatury na jego tvorčestvo. Brno.

DOROVSKÝ, I. (2010): Oda «Volnost»» A. S. Puškina (seminarnaja rabota). Ed.: Ivo Pospíšil. Brno.

DOROVSKÝ, I. (2014): S domovem v srdci. Brno.

HENRI, M. (1995): Alexis de Tocqueville a úskalí demokracie. Praha.

JERJOMIN, M. (1963): Puškin publicist. Moskva.

MEJLACH, B. S. (1949): Putešestvije iz Moskvy v Peterburg Puškina. In: Izvestija AN SSSR, otdelenije literatury i jazyka, 1949, t. VIII, vyp. 3, ijun' - maj, s. 216-228.

Mémoires de fohn TANNER, ou trente années dans les déserts de l'Amérique du Nord (1835). Paris. 
MISIRKOV, K. (2012): O makedonských záležitostech. Přel. Ivan Dorovský. Brno.

POSPÍŠIL, I. (1973): Dynamika rusko-amerických literárních vztahů od počátku do konce 19. století. Universitas, 1973, č. 5, s. 28-35.

POSPÍŠIL, I. (1986): Puškinův „John Tanner“- jeho kontext, smysl a funkce. Československá rusistika, 1986, č. 3, s. 106-111.

POSPÍ̌̌IL, I. (1988): Problém autorského typu: Fadděj Bulgarin. Slavica Slovaca, 1988, č. 4 , s. 366-384.

POSPÍŠIL, I. (1993a): Hořce ironická science fiction Fadděje Bulgarina. Svět literatury, 1993, 5, s. 22-28.

POSPÍŠIL, I. (1993b): Metodologičeskoje značenije tvorčestva literaturnych autsajderov. In: Litteraria Humanitas II, Brno, 347-354.

POSPÍŠIL, I. (1995): Fenomén šílenství v ruské literatuře 19. a 20. století. Brno.

POSPÍŠIL, I. (2002): Až se vyčasí... Úvahy - kritiky - glosy - eseje. Brno.

POSPÍŠIL, I. (2010): Básník, jeho vykladač a souvislosti (Juvenilie Ivana Dorovského jako zárodek badatelské dráhy). In: DOROVSKÝ, I.: Oda «Volnost’» A. S. Puškina (seminarnaja rabota). Ed.: Ivo Pospíšil. Brno, s. 3-12.

POSPÍŠIL, I. (1998): Fadděj Bulgarin jako literární inspirátor. In: Biele miesta II. Univerzita Konštantína Filozofa, Fakulta humanitných vied (katedra rusistiky), Nitra, s. 29-44.

POSPÍŠIL, I. (1999): Na výspě Evropy. Skici a meditace k 2oo. výročí narození A. S. Puškina. Brno.

POSPÍŠIL, I. (2005): Ruský román znovu navštívený. Historie, uzlové body vývoje, teorie a mezinárodní souvislosti: Od počátků $k$ výhledu do současnosti. Brno.

POSPÍŠIL, I. (2006): Problém tzv. cestopisu: statika/dynamika prostoru a lidská existence. In: SPFFBU, Slavica Litteraria, X 9, s. 155-170.

POSPÍŠIL, I. (2006): Romannaja oderžimost’ Aleksandra Puškina. Zagadnienia Rodzajów Literackich, 2006, 49, z. 1-2, s. 5-22.

POSPÍŠIL, I. (2016): On the Margin of Genre Typology or The Hidden Pioneer of Russian Science Fiction (Faddey Bulgarin). Na margo žánrovej typológie skrytého priekopníka ruskej science fiction (Faddej Bulgarin). Slavica Nitriensia, 2016, 1, s. 27-40.

POSPÍŠIL, I. (2018): Žanrovyje innovacii i recepcija Faddeja Venediktovicha Bulgarina $v$ češskoj srede. Pytannja literaturoznavstva / Problems of Literary Criticism, 2018, № 97, s. 191-208.

POSPÍŠIL, I. (2021): Odešel slavista, balkanista, básník a prozaik, makedonský akademik prof. Ivan Dorovský. Proudy, 2021, 1. <https://www.phil.muni.cz/journal/proudy/ portrety/vzpominky/2021/1/pospisil_odesel_slavista_ivan_dorovsky.php>. [online]. [cit. 17. 10. 2021].

PUŠKIN, A.S. (1958): Džon Tenner. In: Polnoje sobranije sočinenij v desjati tomach. Tom sedmoj, Moskva, s. 434-435. 
RAYNAL, G. T. (1780): Histoire philosophique et politique des établissemens et du commerce des Européens dans les deux Indes. Geneva.

ROTHE, H. (1968): N. M. Karamzins europäische Reise: der Beginn des russischen Romans. Bad Homburg, Berlin und Zürich.

SHAW, J. (1966): Puškin on America: His „fohn Tanner“. In: Orbis scriptus. München, S. $739-756$.

SVIN'IN, P. P. (1815, 1818): Opyt živopisnogo putešestvija po Severnoj Amerike. Sankt-Peterburg.

SVIN'IN, P.P. (1813): Sketches of Moscow and St. Petersburg. Philadelphia.

SVIN'IN, P.P. (1814): Sketches of Russia, illustrated with fifteen engravings (1814) by Pavel SVINYIN. London.

TANNER, J. (1940): Narrative of the Captivity and Adventures of Fohn Tanner during Thirty Years Residence among the Indians in the Interior of North America. San Francisco.

TANNER, J. (1830): Narrative of the Captivity and Adventures of Fohn Tanner during Thirty Years Residence among the Indians in the Interior of North America. Prepared for the Press by Edwin James, M. D. New York.

TANNER, J. (1956): V indiánském zajetí. Život a př́běhy fohna Tannera. Přel. Josef Cincibus. Praha.

TOCQUEVILLE de, A. (200o): Demokracie v Americe. Praha.

TOJBIN, J. M. (1980): Puškin i filosofsko-istoričeskaja mysl'v Rossii na rubeže 1820 i 1830 godov. Voronež.

\section{Summary}

\section{Ivan Dorovský and Russian Studies}

The author of the present article reminds the memory of a significant Czech slavist and Balkanist professor Ivan Dorovský: who instead of a standard obituary he applies his analytical editorial text used as a preface to his edition of Dorovskýs student seminar work devoted to the famous Pushkin's didactic poem Freedom. In a chain of contextual case mini studies he manifests how this seminar essay created the grounds of Dorovskýs future scholarly career, especially his tendencies to genre and comparative investigation, to historical and political context which brought him to the team of the famous literary theorist Dionýz Ďurišin, to his conception of specific interliterary communities and to area studies in general.

\section{About the author}

Ivo Pospíšil, Masaryk University, Faculty of Arts, Department of Slavonic Studies, Brno, Czech Republic,ivo.pospisil@phil.muni.cz 
